Colour 73. Second Congress of the International Colour Association, July i 973. Pp. 566. Adam Hilger, London ( $£$ i 2.00)

This collection of the proceedings of the second congress of the International Colour Association held at the University of York follows the original division into sessions. Nine survey lectures covered inter alia retinal physiology, interaction between colour, light, and environment, the pathology of colour vision, and also computerization. The more specialized sessions were devoted to colour vision, the visual system, colour difference measurements, colorimetry, colour rendering and reproduction, colour appearance, analytic and instrumental problems, and colour in a social context, in design and in architecture.

As might be expected, the book is a hotchpotch. Except for the odd survey lecture, its components cannot provide polished and readily consumable information even though there are fortunately some helpful illustrations. One is therefore left with the question why one should spend $£_{12}$ on something that is basically a souvenir for the participants of the Congress. The answer is that some of the papers have some useful references which one might otherwise not have come across.

R. A. Weale

\title{
Augenheilkunde. Ein kurzgefasstes Lehrbuch mit 487 Prüfungs-fragen.
} By F. Hollwich. I973. Pp. 407, 20 figs. Thieme, Stuttgart (DM I8.80)

This book deals with some important topics in ophthalmology and some rare ocular conditions. It is a useful volume for the examination candidate and also for the ophthalmic houseman and general practitioner. The author has avoided discussion of controversial problems such as the cause of glaucomatous cupping. Fluorescein angiography is mentioned only as a diagnostic aid in central serous choroiditis, and tonography and defects due to chromosomal anomalies are not considered. Most of the illustrations are excellent and constructive. Of general interest are the remarks prefacing and summarizing each chapter.

H. Lytton

\section{BOOKS RECEIVED}

Arbeitsmedizinische Fragen in der Ophthalmologie (Problems of Industrial Medicine in Ophthalmology) Vol. 3-4 [Societas Ergophthalmologica Internationalis, 3rd Symposium, Mexico, 1970; $4^{\text {th }}$ Symposium, Budapest, 1972] Edited by H.-J. MertÉ. I974. Pp. 247, 89 figs, bibl. Karger, Basel. (£ 14.30) 